\title{
COMPARISON OF THE FRICTIONAL PROPERTIES OF SEVERAL POPULAR ARBORIST BLOCKS
}

\author{
by Peter S. Donzelli
}

\begin{abstract}
Commercial arborists spend much of the workday managing friction. In some places, friction is needed, but in others it can be a hindrance; the arborist block is one place friction is not wanted. This device is attached to the tree and supports a rope used to lower wood during pruning or removal operations. When a short section of rope is led from the wood to the block, then a much longer section from the block to the ground, friction will cause the force in the short leg to be larger. This short leg of rope, with limited rope fiber, is required to absorb more energy than the corresponding longer leg. In the extreme case, this may lead to failure of the rope, and hence motivates the desire to quantify the friction that may be present in this device. Three blocks were tested for the coefficient of static friction during raising and lowering. The friction coefficient was nonlinear with the load being managed, and ranged from 0.049 to 0.99 over all the loads and among the 3 blocks.
\end{abstract}

Key Words. Arborist block; friction; rigging; dynamic loading; tree removal.

Arborist equipment has evolved significantly in recent years to make work safer, easier, and more efficient. As the tools become more sophisticated, however, it becomes necessary for arborists to be aware of the technical merits of one device over another. This research examines arborist blocks used in rigging operations for tree pruning or removal and sets out to measure the frictional properties of their rotating sheaves. The decision to undertake these measurements came about as part of a larger investigation of the dynamic forces generated by rigging operations in tree care. In performing experiments where forces were measured in a rigging system, we noted discrepancies that could perhaps be attributed to friction in the arborist block. Thus, this second experiment was developed as a way to quantify this effect, and to enhance the former investigation.

In general terms, arborist rigging operations can be described as lowering wood from a tree with the aid of ropes. In many cases, ropes are run over natural crotches in the tree. While this practice is quite common, and often very efficient, it can have damaging effects on both the tree and rope. When suitable natural crotches are unavailable, or the arborist chooses not to use them because of concern about wear on the cambium, a false-crotch device is employed. The more sophisticated of these is the arborist block, essentially a single-sheave pulley with a bushing or bearing supported on a shaft connected to the structural cheek plates. A second shaft is provided at the top of the device as an attachment point for a rope sling to secure the block to the tree. The history of and some design considerations for these devices are given by Blair (1995).

When the block is used for lowering, it is attached to the tree with a rope sling tied in a cow or timber hitch, and a suitable lowering line is run through the block from the back. Next, the working end of the line is attached to a section of wood to be removed (Figure 1). The running end of the line is controlled by a ground worker, perhaps with the aid of some friction device so as to increase the holding force this person can impart. In other experiments a straight, vertical trunk section is lowered with the block tied below the trunk section being removed. Additionally, the running end of the lowering line was rigidly secured at the base of the tree, a procedure that produces a dramatic dynamic load on the rigging system, but one that is sometimes required to avoid obstacles below the work area. Once the wood is released, it falls twice the distance of the block to the cut, and its kinetic energy is absorbed by the lowering line. Force measurements were obtained where the lowering line was attached to the base of the tree (the line pull) and where the block was attached to the tree (the reaction force). If the block were frictionless, and both parts of line were parallel and directed vertically, a balance of forces predicts the reaction force at the block to be twice the line pull measured at the base of the tree. In 3 trials, the reaction force exceeded twice the line pull by $7.5 \%$, $10.5 \%$, and $9.3 \%$. 


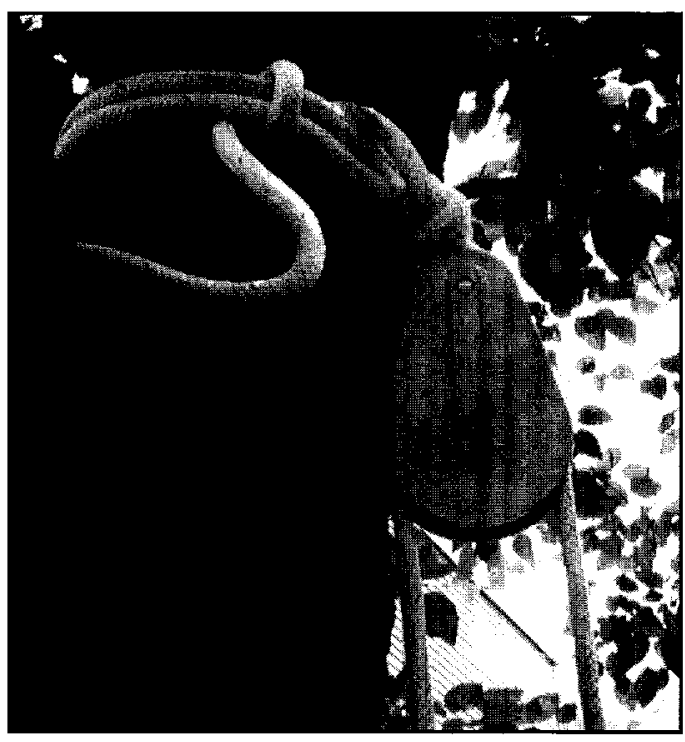

Figure 1. Photograph of an arborist block installed in a tree. A 19-mm (3/4-in.) double-braid polyester sling with an eye spliced in one end is affixed to the block and tied with a cow hitch to the main stem. A second 14.3-mm (9/16-in.) double-braid lowering line is run from the back (left in this figure) and over the sheave. The working end of the lowering line is to the right, and the running end is to the left. Note how the cheek plates of the block will protect the line from abrasion with the trunk.

Among the possible sources for this additional force are the weight of the block, sensitivity of the force measurement devices, and the sampling rate of these devices. Careful consideration discounted these sources in favor of friction at the block, and this magnitude of friction would be a significant finding. If there were friction at the block, then the force toward the working end of the lowering line-the shorter leg of rope-would be greater than that toward the running end. The lowering line effectively functions as a large spring, with the rope fibers absorbing the energy of the falling wood. Friction at the block means the shorter leg of line must absorb a greater amount of energy but with a lesser amount of fiber to accomplish this. In contrast, with a frictionless block, the entire length of rope from the working end, through the block and to the ground, is available to absorb the energy. Thus, the significance of this investigation is that it provides the commercial arborist with addi- tional data for selecting equipment, aids in keeping a record of the loading a particular line has experienced, and may go toward improving the safety and efficiency of rigging operations.

\section{MATERIALS AND METHODS}

Three commercially available arborist blocks were purchased for this experiment: a BGF (BGF Enterprises, Inc., West Grove, PA), a Hobbs ${ }^{\mathrm{TM}}$ (Sierra Moreno Mercantile Co., Big Pool, MD), and a Wall (Wall Safety Products, Kannapolis, NC). Collectively, these represent the most popular devices in use today; they are shown in Figure 2. Each block in this study is constructed with a bushing supporting the load-bearing sheave and is sized to accept $19-\mathrm{mm}$ (3/4-in.) rope. The BGF and Hobbs are constructed of aluminum for both the body and sheaves, while the Wall is constructed of steel. The BGF has its design limits for load and rope size stamped into the body, the Hobbs has this technical information in a separate user's guide and instruction manual, and the Wall has an ANSI identification number but no other data.

All of the blocks tested are designed so that the upper shaft can be removed to aid in placement of a spliced-eye sling. The lower shaft of the BGF is secured with 2 roll pins, the Hobbs has an allen-key shoulder bolt secured with an allen-key set screw, and the Wall has a nut welded to one cheek plate, with a shoulder bolt threaded into this from the opposite side and welded in the locked position. Each block was carefully disassembled, and the sheaves and shafts were measured with a vernier caliper and/ or a micrometer. Each sheave was also weighed with a spring scale. In the case of the Wall, the necessary weld was filed away manually and a thread-locking fluid was applied after reassembly.

For a mechanical device with a dry bushing, elementary mechanics can be used to determine the friction coefficient. A simple analogy defines the friction coefficient, $\mu$ : If it takes a horizontal force of 50 newtons $(N)$ to slide a $200-\mathrm{N}$ crate across a level surface, then the friction coefficient is $1 / 4$, or the ratio of the tangential force to the normal force on the interface. In the rotational system of the block, it will correspondingly take less than $200 \mathrm{~N}$ of force to lower a $200-\mathrm{N}$ load, and more than $200 \mathrm{~N}$ to raise that same load, although the exact coefficient of friction is now a function of the geometry of the sheave and bushing. 


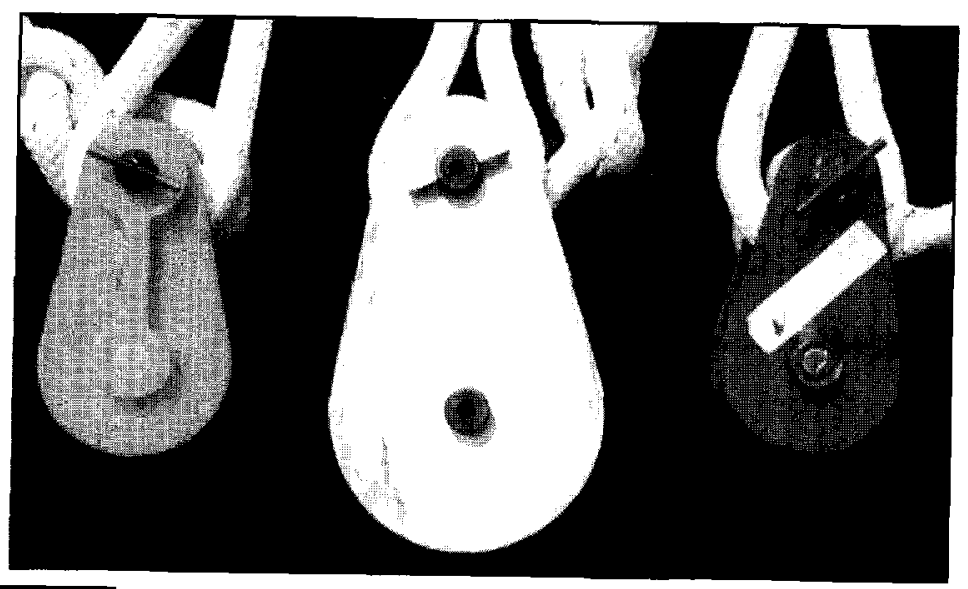

(a)

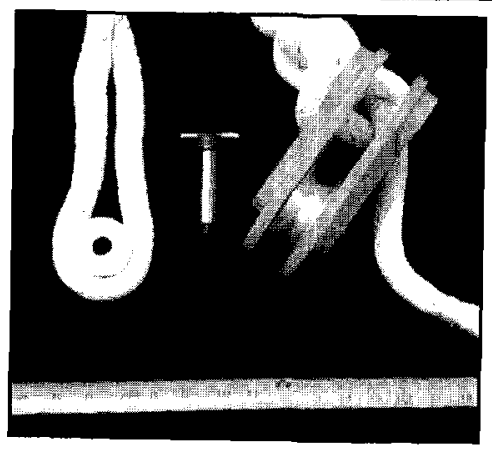

(b)

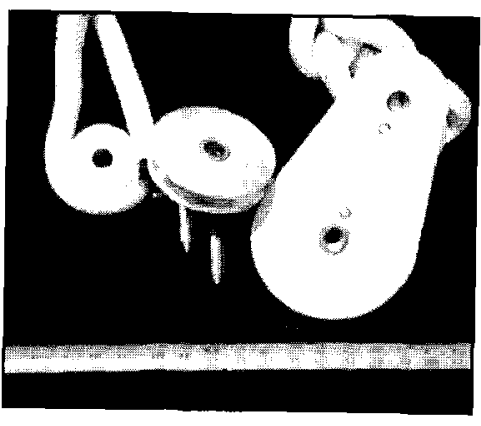

(c)

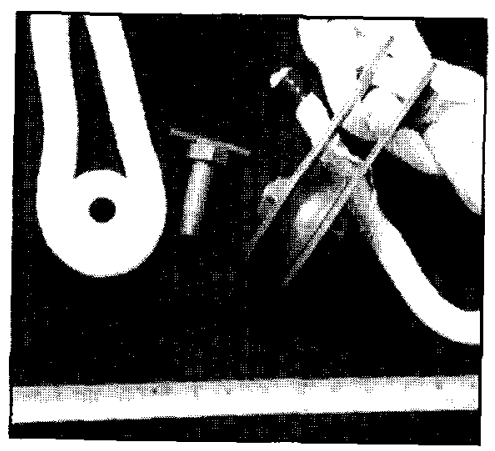

(d)

Figure 2. Photographs of the 3 blocks used in this study. They are the BGF, Hobbs, and Wall, from left to right. They are shown together (a), then individually while apart for measurement (b-d). A scale in inches is shown in b through $d$.

Figure 3 a shows a schematic diagram of the bushing and sheave when the block is used to lower a load, L. In Figure 3b, a free-body diagram of the same system is provided. Applying Newton's first law produces equations representing the balance of force and moment, and written in terms of the geometry, forces, and friction coefficient. Following the presentation given by Meriam and Kraige (1986), the equations of equilibrium are written for point $A$, the point of contact between the shaft and sheave. Note how the frictional force will cause the shaft to roll down the side of the sheave. In contrast, the contact point will be to the left of the center (point $O$ ) when a load is being raised. The reaction force, $\mathbf{R}$, is equal to the sum of the load, $\mathbf{L}$, lifting force, $\mathbf{F}$, and weight of the sheave, $\mathrm{W}$, and will be directed vertically. The friction coefficient is defined as the ratio of the tangential and normal components of the reaction force at the contact point,

$$
\mu=\frac{\mathbf{R}_{t}}{\mathbf{R}_{n}}=\tan (\theta) \cong \sin (\theta),
$$

where tangent and sine can be equated for small angles. This same angle defines the horizontal component of distance from point $O$ to point $A$, known as the friction radius $\left(r_{p}\right)$

$$
r_{f}=r_{s} \sin (\theta)
$$

where $r_{s}$ is the radius of the shaft. The moments due to the load $\left(\mathbf{M}_{\mathrm{L}}\right)$ and lifting force $\left(\mathbf{M}_{\mathrm{F}}\right)$ about point $\mathrm{A}$ are

$$
\mathbf{M}_{L}=\left(r-r_{f}\right) \mathbf{L} \text { and } \mathbf{M}_{f}=\left(r+r_{f}\right) \mathbf{F} \text {. }
$$

where $r$ is the tread radius of the sheave. Thus, the moment equilibrium about point $A$ is

$$
\sum M_{A}=\left(r-r_{f}\right) \mathbf{L}-r_{f} W-\left(r+r_{f}\right) \mathbf{F}=0 .
$$

Now substituting from equations (1) and (2) into (4) and solving for the friction coefficient,

$$
\mu_{\text {down }}=\frac{r(\mathbf{L}-\mathbf{F})}{r_{s}(\mathbf{F}+\mathbf{W}+\mathbf{L})} .
$$




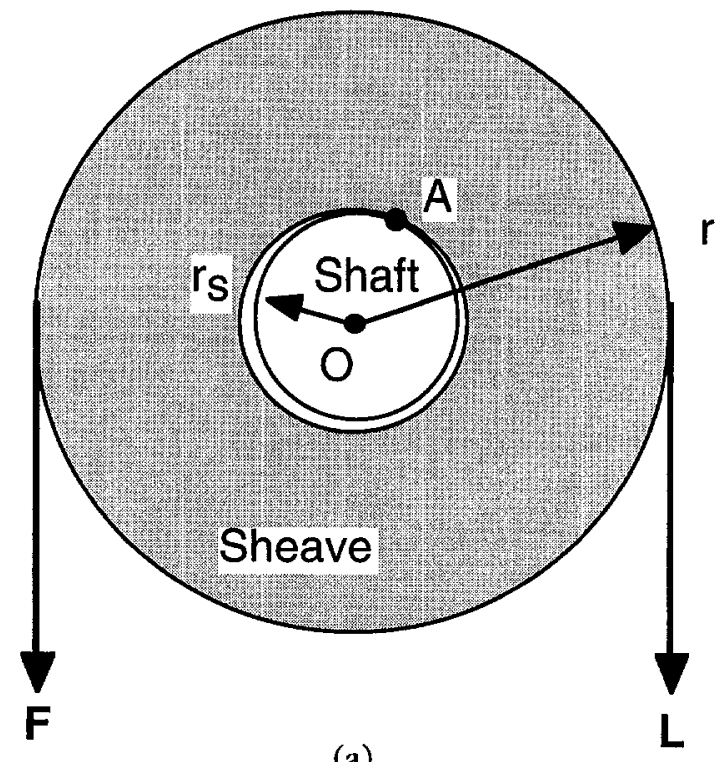

(a)

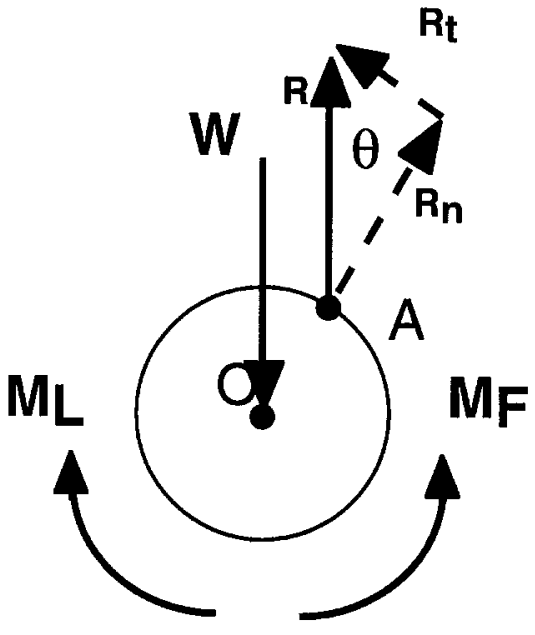

(b)

Figure 3. Geometry and free-body diagram of an arborist block used to lower a load, L. A force, F, less than $\mathrm{L}$ is required to lower the load. The sheave has a tread radius $r$, and the load bearing shaft has a radius $r_{5}$ (a). Point $O$ is the center of rotation, and point $A$ is the point of contact of the shaft with the sheave. The vertical reaction force, $R$, balances the applied loads and the weight of the sheave, W. The reaction makes and angle $\theta$ with the line $\mathrm{OA}(\mathrm{b})$.

Following similar steps for motion upward, the expression for the friction coefficient in that case is

$$
\mu_{u p}=\frac{r(\mathbf{F}-\mathbf{L})}{r_{s}(\mathbf{F}+\mathbf{W}+\mathbf{L})},
$$

although one expects that a given block either raising or lowering a given load will have the same value for the friction coefficient.

The derivation above is valid at the instant where there is impending motion, either up or down, because no dynamic forces were included in the equilibrium relations. Thus, it will produce a measure of the static coefficient of friction, which is known to be greater than the dynamic friction. To account for the possibility of a friction coefficient that varies with the load being managed, readings were taken at 5 load levels: $245,489,734,979$, and 2,224 N (55, $110,165,220$, and $500 \mathrm{lbf}$ ). An ED-2000 electronic dynamometer (Dillon Force Measurement Products \& Systems, Fairmont, MN), with a 5,000 lbf capacity and $1 \mathrm{lbf}$ resolution was used to obtain the weights and also to record the lifting and lowering forces. (Note that all experimental measurements with the
ED-2000 were obtained in the English system of units and have been converted.) The objects were first weighed by suspending the dynamometer by its upper shackle and attaching the objects at the bottom. Next, each block was suspended by its upper sheave and a length of $12.7 \mathrm{~mm}$ (1/2 in.) rope (True Blue $^{\mathrm{TM}}$, Samson Ropes, Ferndale, WA) to be used as the rigging line was placed over the sheave. The load was attached to the working end of the line, the dynamometer was attached in-line between the block and the running end, and a mechanical advantage system was used to tension the line. After ensuring that the 2 legs of line were parallel when exiting the block, the mechanical advantage was taken up until the object just began to move upward, at which point the force was recorded. Then the force was reduced until the object began to move downward, and the force again recorded.

\section{RESULTS AND DISCUSSION}

Measurement data for the 3 blocks are given in Table 1. While the blocks were disassembled, visual observations were also made. Each of the blocks had 
Table 1. Measurement data for the 3 arborist blocks used in this study. Refer to Figure 3a for the interpretation of the geometric parameters. Data were recorded in inches or pounds-force (lbf), at the accuracy given by the values in parentheses.

\begin{tabular}{llll}
\hline Block & $\begin{array}{l}\text { Tread radius } \\
\text { mm (in.) }\end{array}$ & $\begin{array}{l}\text { Shaft radius } \\
\text { mm (in.) }\end{array}$ & $\begin{array}{l}\text { Sheave weight } \\
\mathrm{N}(\mathrm{lb})\end{array}$ \\
\hline BGF & $27.559(1.0850)$ & $9.525(0.375)$ & $2.2241(0.5)$ \\
Hobbs & $52.324(2.060)$ & $9.525(0.375)$ & $5.8383(1.3125)$ \\
Wall & $29.21(1.150)$ & $9.3898(0.370)$ & $6.3943(1.4375)$ \\
\hline
\end{tabular}

a bushing to support the main sheave on the shaft. All of the sheaves turned freely when moved by hand, or by pulling on a rope run over the sheave, although the Wall block had audible friction with the cheek plates. The BGF appeared to have the finest surface finish on its sheave. Some surface scores and pitting were noted on Hobbs, while the Wall, with a painted finish, had some weld debris in the tread. Because fiber only supports load in tension, it is important not to bend rope sharply while loaded. The Cordage Institute recommends that a rotating sheave ideally have a diameter 8 times the diameter of the rope it supports (The Cordage Institute, 1993). The farther below 8 this ratio falls, the greater the strength reduction that will occur in the rope. The Hobbs comes closest to this with a ratio of 5.5 to 1 ; the BGF and Wall have ratios near 3 to 1 . Also, one can see from equation (4) that, for a given friction coefficient, as the tread radius increases, the lowering force approaches the load, independent of the friction coefficient. This means that even a block with a large amount of friction can be made efficient if the sheave were large enough. So, in addition to the frictional properties, the arborist should consider geometry as a factor affecting the strength reduction and differential loads applied to a lowering line.

Forces required for impending motion upward or d o w n w a d while managing each of the 5 loads are given in Table 2. Due
Table 2. Measured line pull required for impending motion upward or downward for different loads. Values in newtons $(N)$ with English equivalents given in pounds-force (lbf) in parentheses.

\begin{tabular}{llllllllllll}
\hline & \multicolumn{2}{c}{$245 \mathrm{~N}$} & \multicolumn{2}{c}{$489 \mathrm{~N}$} & \multicolumn{2}{c}{$734 \mathrm{~N}$} & \multicolumn{2}{c}{$989 \mathrm{~N}$} & \multicolumn{2}{c}{$2224 \mathrm{~N}$} \\
Block & $\mathrm{Up}$ & Down & $\mathrm{Up}$ & Down & Up & Down & Up & Down & \multicolumn{2}{c}{$\begin{array}{l}\text { Up } \\
(500 \mathrm{lbf})\end{array}$} \\
\hline BGF & 289.1 & 151.2 & 596.1 & 360.3 & 898.5 & 564.9 & 1218.8 & 774.0 & 2602.2 & 1957.2 \\
& $(65)$ & $(34)$ & $(134)$ & $(81)$ & $(202)$ & $(127)$ & $(274)$ & $(174)$ & $(585)$ & $(44)$ \\
Hobbs & 240.2 & 169.0 & 498.2 & 391.4 & 774.0 & 622.7 & 1067.6 & 849.6 & 2357.6 & 2135.1 \\
& $(54)$ & $(38)$ & $(112)$ & $(88)$ & $(174)$ & $(140)$ & $(240)$ & $(191)$ & $(530)$ & $(480)$ \\
Wall & 298.0 & 160.1 & 605.0 & 369.2 & 907.4 & 551.6 & 1216.8 & $(-)$ & 2580.0 & 1854.9 \\
& $(67)$ & $(36)$ & $(136)$ & $(83)$ & $(204)$ & $(124)$ & $(274)$ & & $(580)$ & $(417)$ \\
\hline
\end{tabular}

to experimental difficulties, one measurement could not be recorded. The data are as expected, with lowering forces less than the load and lifting forces greater, except for one measurement. In lifting a 245-N load with the Hobbs block, the recorded force was less than this value; most likely a limitation of the sensitivity of the ED-2000.

Data from Tables 1 and 2 are now substituted into either equation (5) or (6) to produce values of the friction coefficient. These results are given graphically in Figure 4. Curves for lowering or raising a load are nonlinear with the load being managed and have the opposite curvature, although at higher loads the values approach the same asymptote. In Figure 4 (bottom illustration), the negative friction coefficient is due to the erroneous force reading for raising a 245-N load with the Hobbs block.

Each of the blocks is rated for a working load significantly greater than the $2.2 \mathrm{kN}$ used in this study. If the bushings are of the oilite type (this could not be verified by inspection, and is not specified by the manufacturers), then one would expect that at higher loads the friction mechanism would change from dry to lubricated. This, at least in part, explains the nonlinear nature of the curves. Additionally, at lower loads the measurement sensitivity is a greater percentage of the total value. For example, at the lowest load considered, a 1-lb increase in the measurement of lowering force for the BGF block results in almost a $6 \%$ decrease in the computed friction coefficient. At the highest load, this is less than a $2 \%$ difference. Thus, one limitation of the study is that higher loads are more representative of what may occur in the field-and cause the equipment to operate in a more favorable range-but could not be tested with our experimental apparatus. 
Another limitation in this study is the restriction to static friction. In the field, the block will experience dynamic loading of some type, although this was not considered here because of the many additional variables that would have to be accounted for in the experimental design. With a block functioning under ideal conditions, the rope wraps over the upper 180 degrees of the sheave, and the friction between the rope and sheave is enough to overcome that between the sheave and shaft, causing the sheave to rotate. The experiments conducted here did not differentiate between these 2 effects although, again, this will be most significant at lower loads and may be one factor affecting the curvature of the graphs in Figure 4. This is relevant to practical situations in which the block is attached below the wood being removed. In these cases, there will be less rope in contact with the sheave; thus, there may well be considerable sliding of the rope against the sheave before it begins to rotate. Also, it is this type of rigging that generally produces the largest dynamic loads. For many reasons, dynamic loading should be avoided in arborist rigging operations, although it can never be completely eliminated. Understanding the properties of arborists blocks under these conditions is a topic worthy of further study.

\section{CONCLUSIONS}

An experimental study was conducted to measure the static coefficient of friction of several popular arborist blocks. This study was motivated by earlier rigging experiments that noted significantly different forces in the legs of rope on opposite sides of a block. For a given load supported on the block, a greater force is required to initiate motion upward, and a lower force will initiate motion downward. Using engineering concepts for friction of dry bushings, the measurements of force, along with the geometry of the sheaves and bushings, have been used to determine the friction coefficient for 3 blocks. At a load representative of what may be encountered in practical use, the Hobbs block had the most favorable coefficient $(0.12)$, followed by the BGF $(0.18)$ and the Wall $(0.27)$. These values almost completely explain the discrepancies noted in earlier research measuring forces in a rigging system. Calculations show the most significant design factor influencing this result may well be the tread diameter of

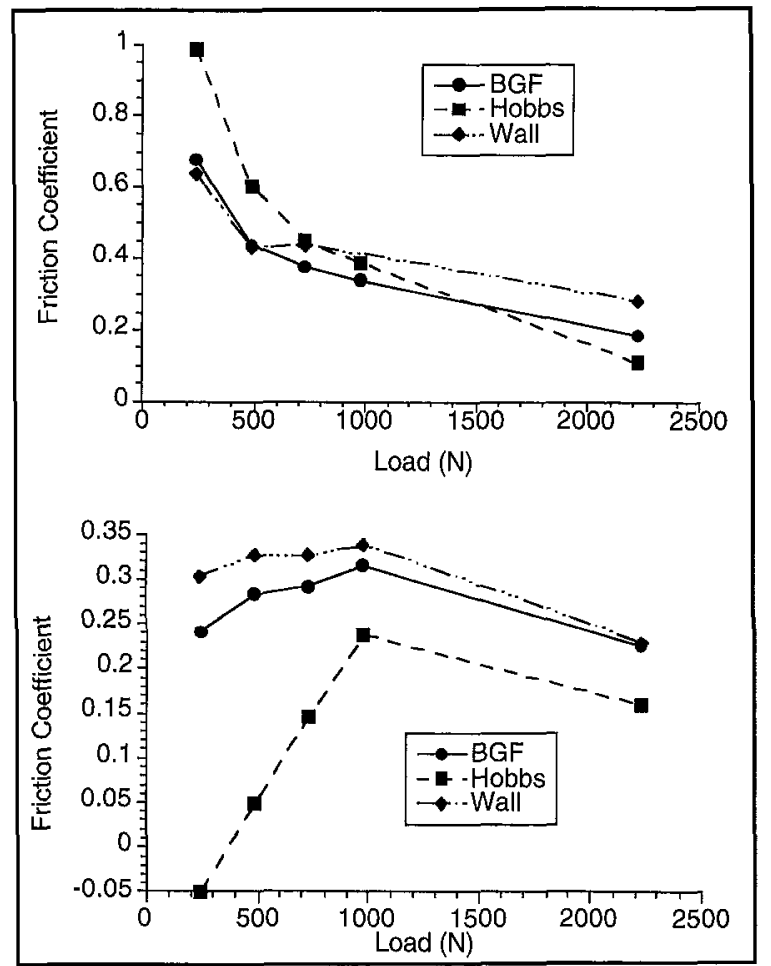

Figure 4. Plots of the friction coefficient with load for lowering (top) or raising (bottom) an object.

the sheave used rather than the frictional properties of the bushing itself. With a larger diameter, in effect functioning as a lever arm, the mechan-ical advantage of the sheave can overcome the frictional losses of the bushing. The larger diameter has the additional benefit of providing a more favorable bend ratio for the rope that is supporting a load.

This study has been successful in explaining the differences previously observed in ongoing experiments concerned with arborist rigging. Despite this success, several additional questions remain to be answered. A primary objective would be to extend the present methods to higher loads, to ensure that the nonlinear behavior of the friction coefficient with load has reached an asymptote. Two difficulties arise at higher loads: first is the equipment needed to raise or lower large loads with fine control, and second is the ability to distinguish the point of impending motion. Another objective would be to design an experiment that could recover the dynamic coefficient of friction. The simplest experiment would measure friction for a rope moving at constant speed and with 
a fixed load. More complex would be measuring the friction encountered when a falling object is stopped by a rope run through the arborist block.

These results and observations go to making the process of rigging safer and more efficient for the commercial arborist. Recommendations from rope manufacturers suggest that arborists use ropes at only $10 \%$ of the average breaking strength; general industrial use is often at $20 \%$. The more conservative requirement comes about because arborists often use ropes to arrest falling objects, thus producing large dynamic forces. In addition, manufacturers also designate the load cycles to failure a rope can support; at higher loads there are fewer cycles to failure. In the absence of dynamic loading, one can estimate the weight of wood being lowered and can maintain the desired working load limit for the ropes. With dynamic loading, however, the forces are determined not only by the weight of wood but also by the amount of rope fiber available to absorb the impact. Friction will effectively limit the amount of fiber, and knowledge of these effects can be used in assessing the loading history of a particular line and thus its serviceable life with regard to working load limit and load cycles to failure. If ropes are consistently used above these limits, fiber damage will accumulate and eventually lead to premature failure of the line. With significant friction in an arborist block, the lowering line is differentially loaded, with greater forces in the end attached to the load. It is essential that this be accounted for in determining when to retire a given line, and the friction coefficients reported here can aid in making that determination.

\section{LITERATURE CITED}

Blair, D.F. 1995. Arborist Equipment: A Guide to the Tools and Equipment of Tree Maintenance and Removal. International Society of Arboriculture, Champaign, IL. $291 \mathrm{pp}$.

The Cordage Institute. 1993. Fiber Rope Technical Information Manual. The Cordage Institute, Hingham, MA.

Meriam, J.L., and L.G. Kraige. 1986. Engineering Mechanics. Vol. I, Statics. (2nd ed.). Wiley, New York, NY. 454 pp.
Acknowledgements. The author is supported in part by a John Z. Duling grant from the International Society of Arboriculture Research Trust. He gratefully acknowledges equipment donations from the American Group, Samson Division and Shelter Tree, Tree Care Products. Assistance from ArborMaster Training, Inc.; RopeWorks, Splicing Rope Products; and Mark Mertz of the Norfolk County (MA) Agricultural and Technical High School has been essential in completing this research.

\section{Department of Biomedical Engineering Rensselaer Polytechnic Institute. \\ Troy, NY 12180-3590}

Résumé. Les arboriculteurs commerciaux passent une bonne partie de leur journée de travail à gérer les physiques de la friction. Dans certaines situations, la friction est nécessaire, mais dans d'autres elle peut être une entrave. La poulie est un de ces endroits où la friction est non désirable. Cet équipement est attaché à l'arbre et supporte une corde utilisée pour descendre les pièces de bois durant les opérations d'élagage ou d'abattage. Lorsqu'une courte section de corde est dirigée depuis la pièce de bois vers la poulie, une plus longue section descend fréquemment vers le sol. La courte section de corde est requise pour absorber plus d'énergie que la section correspondante plus longue, mais elle est limitée à la fibre de la corde. dans les cas extrêmes, cela peut conduire au bris de la corde, d'où l'intérêt de quantifier la friction qui peut être présente dans la poulie. trois poulies ont été testées pour le coefficient de friction statique durant l'élévation et la descente. Le coefficient de friction n'était pas linéaire en fonction de la charge manipulée; il se situait entre 0,049 et 0,99 selon les charges et parmi les trois poulies.

Zusammenfassung. Baumpfleger verbringen viel Zeit am Tag mit der Bewältigung von Reibungswiderstand. In einigen Fällen ist er erforderlich, in anderen kann er hinderlich sein. Der Umlenkpunkt ist ein Ort, wo dieser Widerstand nicht erwünscht wird. Diese Einrichtung hier wird am Baum befestigt und unterstützt ein Seil, welches zum Ablassen von Stammteilen während eines Rückschnittes oder bei Fällungen genutzt wird. Wenn ein 
kurzes Seilende vom Stammteil zum Umlenkpunkt führt und das lange Ende von dem Umlenkpunkt zum Boden, dann verursacht der Reibungswiderstand, daß die Kraft in dem kurzen Ende größer ist. Dieses kurze Seilende muß mehr Energie aufnehmen als das korrespondierende lange Ende, allerdings mit begrenzter Seilfaser. Im Extremfall kann das zum Versagen des Seiles führen. Das führt zu dem Wunsch, den Reibungswiderstand an diesem Umlenkpunkt zu quantifizieren. Es wurden 3 Umlenkrollen getestet, um den Koeffizienten des statischen Reibungswiderstands während des Ablassens oder Hochziehens zu bestimmen. Der Reibungskoeffizient verhielt sich nicht linear zu der bewegten Kraft und rangierte in dem Bereich von 0.49 bis 0.99 bei allen Lasten und zwischen den drei getesteten Rollen.

Resumen. Los arboristas comerciales gastan gran parte de su día de trabajo manejando la física de la fricción. En algunos lugares la fricción es necesaria, pero en otros puede ser un obstáculo. La polea es uno de los lugares en que la fricción no es deseada. Este dispositivo es atado al árbol y soporta una cuerda usada para bajar la madera durante la poda $u$ operaciones de remoción. Mientras una sección corta de cuerda es llevada desde el tronco hasta la polea, frecuentemente una sección mucho mayor se lleva hasta el suelo. El trecho corto de cuerda es requerido para absorber más energía que el correspondiente trecho largo, pero con limitada fibra de cuerda. En el caso extremo esto puede llevar a una falla de la cuerda $y$, por consiguiente, motiva el deseo de cuantificar la fricción que puede estar presente en la polea. Tres poleas fueron examinadas para observar el coeficiente de fricción estática durante el levantamiento y descenso. El coeficiente de fricción fue no lineal con el manejo de carga y fluctúa entre 0.049 y 0.99 sobre todas las cargas y entre las tres poleas. 